Article

\author{
JAVAID, A. ${ }^{1 *}$ \\ AFZAL, L. ${ }^{1}$ \\ SHOAIB, A. ${ }^{1}$
}

\section{Biological Control of Charcoal Rot of Mungbean BY Trichoderma harzianum AND SHOOT DRY BIOMASS OF Sisymbrium irio}

\section{Controle Biológico de Podridão de Carvão em Feijão-Mungo por \\ Trichoderma harzianum e Biomassa Seca de Rebento de Sisymbrium irio}

\begin{abstract}
A pot experiment was carried out for the biological control of charcoal rot on mung bean (Vigna radiata), caused by Macrophomina phaseolina. Pot soil was made sick with an inoculum of M. phaseolina. Dried powdered leaves of Sisymbrium irio, a weed from the Brassicaceae family, were mixed in soil at 1,2 and $3 \%(\mathrm{w} / \mathrm{w})$ with and without the application of Trichoderma harzianm, a fungal biological control agent. The highest grain yield $\left(3.62 \mathrm{~g} \mathrm{pot}^{-1}\right)$ was recorded in a combined application of T. harzianum and $1 \%$ S. irio leaf amendment, which was $62 \%$ and $805 \%$ higher than negative and positive control treatments, respectively. The application of $S$. irio leaf amendment and $T$. harzianum generally enhanced leaf protein, sugar and chlorophyll contents, and catalase activity. This study concludes that $T$. harzianum in combination with $1 \%$ dry leaves of $S$. irio as a soil amendment can be used to achieve the best grain yield under biotic stress of $M$. phaseolina.
\end{abstract}

Keywords: charcoal rot, Macrophomina phaseolina, plant physiology, Sisymbrium irio, Trichoderma harzianum, Vigna radiata.

RESUMO - Foi conduzido um teste em casa de vegetação para o controle biológico da podridão de carvão em feijão-mungo (Vigna radiata), provocada por Macrophomina phaseolina. O solo dos vasos foi infectado com um inóculo de M. phaseolina. Folhas secas pulverizadas de Sisymbrium irio , uma planta daninha da família das Brassicaceae, foram misturadas no solo em 1, 2 e 3\% (p/p), com e sem a aplicação de Trichoderma harzianm Rifai, um agente biológico de controle de fungos. $O$ rendimento máximo em grão (3,62 $\left.\mathrm{g}_{\text {vaso }}^{-1}\right)$ foi registrado com a aplicação combinada de $\mathbf{T}$. harzianum e $1 \%$ de corretivo de $\boldsymbol{S}$. irio, tendo sido $62 \%$ e $805 \%$ maior que o dos tratamentos de controle positivo e negativo, respectivamente. A aplicação de S. irio e T. harzianum, em geral, aumentou os teores de proteinas, açúcares e clorofila das folhas, bem como a atividade de catalase. O presente estudo conclui que T. harzianum combinado com $1 \%$ de folhas secas de S. irio como corretivo de solo pode ser usado para alcançar o maior rendimento em grão sob o estresse biótico de M. phaseolina.

Palavras-chave: podridão de carvão, Macrophomina phaseolina, fisiologia das plantas, Sisymbrium irio, Trichoderma harzianum, Vigna radiata.
* Corresponding author:

<arshadjpk@yahoo.com>

Received: June 25, 2016

Approved: August 3, 2016

Planta Daninha 2017; v35:e017165756

1 Institute of Agricultural Sciences, University of the Punjab, Lahore, Pakistan. 


\section{INTRODUCTION}

The mung bean (Vigna radiata) is an economically important leguminous crop native to the Indian Subcontinent and is mainly cultivated in Pakistan, China, India and countries of Southeast Asia, as well as in hot and dry regions of Southern US and Southern Europe (Nair et al., 2015). It is a significant pulse crop in Pakistan, cultivated on 225.4 thousand hectares with an annual production of 11.3 thousand tons and a yield of $461 \mathrm{~kg}$ per hectare (Agricultural Statistics of Pakistan, 2011). It is an important source of carbohydrates (59-65\%) and dietary proteins (24-28\%) and gives about 3,400 kJ energy kg-1 of dry seeds (USDA, 2010). It is a useful food for children and elderly people because it can be digested more easily than other legumes. Besides, it is also used as a feed for live stock and green manure to improve soil nutrients (Nair et al., 2013). This valuable crop is attacked by the charcoal rot disease, caused by the soil-borne plant pathogen M. phaseolina (Fuhlbohm et al., 2013). This ubiquitous fungal pathogen is common in the tropics and subtropics where it causes diseases in more than 500 plant species including angiosperms and conifers (Dhingra and Sinclair, 1978).

Although some chemical fungicides have proven effective against $M$. phaseoli (Ilyas et al., 1975), so far no registered fungicide is available in the market against this fungal pathogen. There are many reports in the past and recent literature saying that plant extracts and soil amendment with certain plant species can be effective in managing plant diseases (Lewis and Papavizas, 1971; Javaid and Iqbal, 2014; Javaid and Rauf, 2015; Khurshid et al., 2016). In recent past, Javaid and Saddique (2012) reported that charcoal rot in mung bean can be markedly suppressed by soil amendment with Datura metel. Similarly, Javaid et al. (2015) found extracts of the allelopathic grass Imperata cylindrica very effective in suppressing in vitro growth of M. phaseolina. Members of the Brassicaceae family, including both cultivated viz. Brassica spp., and a weed named Coronopus didymus are known to present antifungal activities against a variety of soil-borne fungal phytopathogens (Ramirez-Villapudua and Munnecke, 1988; Troncoso et al., 2005; Javaid and Iqbal, 2014). However, such studies on the Brassicaceous weed S. irio are invariably lacking. The present study was, therefore, conducted to investigate the disease management potential of $S$. irio as soil amendment alone or in combination with the biological control agent Trichoderma harzianum.

\section{MATERIAL AND METHODS}

\section{Pot experiment}

For the preparation of fungal inocula, $1.0 \mathrm{~kg}$ of pearl millet seeds was boiled and double autoclaved for 30 minutes in polythene bags. After sterilization, seeds were cooled at room temperature and inoculated with the fresh culture of $M$. phaseolina under aseptic conditions. The inoculated seeds were incubated at $28{ }^{\circ} \mathrm{C}$ for 10 days. An inoculum of T. harzianum was also similarly prepared.

Pots with a $15 \mathrm{~cm}$ diameter and a $14 \mathrm{~cm}$ depth were filled with soil at $1.0 \mathrm{~kg} \mathrm{pot}^{-1}$. M. phaseolina inoculum was mixed with the pot soil $\left(15 \mathrm{~g} \mathrm{pot}^{-1}\right)$ and watered. Similarly, inoculum of $T$. harzianum was also mixed in the soil of the respective pots and watered. Control pots without any inoculation of either M. phaseolina or T. harzianum received the same amount of boiled pearl millet seeds. After 7 days, dried and powdered leaf material of S. irio was mixed in the soil at $1 \%$, $2 \%$ and $3 \%$ in the respective pots. Pots of positive control treatment only received the $M$. phaseolina inoculum, whereas pots of negative control treatment were without any fungal inoculum or dry powdered S. irio leaves.

The following 9 treatments were used in the pot study, in a completely randomized design with five replications:

\footnotetext{
$\mathbf{T}_{1} \quad-$ Control treatment

$\mathbf{T}_{2} \quad+$ Control treatment [only $M$. phaseolina (MP) inoculation]

$\mathbf{T}_{\mathbf{3}} \quad \mathrm{MP}+1 \%$ leaf dry biomass (LDB)
} 


$\begin{array}{ll}\mathbf{T}_{\mathbf{4}} & \mathrm{MP}+2 \% \mathrm{LDB} \\ \mathbf{T}_{\mathbf{5}} & \mathrm{MP}+3 \% \mathrm{LDB} \\ \mathbf{T}_{\mathbf{6}} & \mathrm{MP}+\mathrm{T} . \text { harzianum }(\mathrm{TH}) \\ \mathbf{T}_{\mathbf{7}} & \mathrm{MP}+1 \% \mathrm{LDB}+\mathrm{TH} \\ \mathbf{T}_{\mathbf{8}} & \mathrm{MP}+2 \% \mathrm{LDB}+\mathrm{TH} \\ \mathbf{T}_{\mathbf{9}} & \mathrm{MP}+3 \% \mathrm{LDB}+\mathrm{TH}\end{array}$

Pots were watered and kept for 10 days under natural conditions. Thereafter, healthy mung bean seeds of even size were surface sterilized with $1 \%$ solution of sodium hypochlorite for 3 minutes and ten seeds per pot were sown. Plants were irrigated with tap water whenever required. Plants were harvested 75 days after sowing. Data regarding plant survival percentage; plant height; dry weight of root and shoot; number, length and weight of the pods; and grain yield were recorded.

\section{Physiological studies}

The total soluble protein contents were assessed according to Lowry et al. (1951). For the sugar estimation, the protocol given by Nelson (1944) was adopted. Chlorophyll extraction was performed by homogenizing $500 \mathrm{mg}$ of fresh leaf material with $10 \mathrm{~mL}$ of chilled $80 \%$ acetone. The resulting homogenate was centrifuged for 15 minutes and the supernatant was analyzed for chlorophyll content (Arnon, 1949). Relative water contents were determined by measuring the fresh weight of a leaf. The leaf was then immersed in distilled water and left for 24 hours. Thereafter, the fully turgid leaf was weighed again. The leaf was dried in an electric oven at $70{ }^{\circ} \mathrm{C}$. The relative water contents (RWC) of the leaf were calculated according to Wheatherley (1950).

RWC $=($ fresh mass - dry mass $) /($ saturated mass - dry mass $) \times 100$

Catalase (CAT) activity was determined according to the method given by Maehly and Chance (1967) and was expressed as the number of $\mathrm{H}_{2} \mathrm{O}_{2}$ molecules used $\mathrm{min}^{-1} \mathrm{mg}^{-1}$ protein.

\section{Statistical analysis}

Standard errors of the means of five replicates were calculated using the MS Excel program. All data were submitted to analysis of variance (ANOVA) and the significant difference ( $\mathrm{P} \leq 0.05)$ among the treatment means was determined by Tukey HSD tests using the computer software Statistics 8.1.

\section{RESULTS AND DISCUSSION}

\section{Effect of soil amendments on plants survival percentage}

The number of mung bean plants survived in negative control treatment was $100 \%$. The survival percentage of plants was reduced by $0-76 \%$ in different treatments, compared to the negative control treatment. In positive control treatment, there was a significant $(\mathrm{P} \leq 0.05)$ reduction $(52 \%)$ in the survival of plants. There was a $39 \%$ increase in plant survival in different doses of leaf manure of $S$. irio over positive control treatment (Figure 1). Earlier studies reported that the incorporation of Brassicaceous plant materials in the soil significantly reduced the disease incidence and severity due to Alternaria alternata (Troncoso et al., 2005), Rhizoctonia solani (Manning and Crossan, 1969), Fusarium oxysporumf. sp. gladioli (Riaz et al., 2010), A. euteiches (Muehlchen et al., 1990), Verticillium dahliae (Subbarao et al., 1994) and Sclerotium rolfsii (Javaid and Iqbal, 2014). Members of this family are known to produce glucosinolates (Sun et al., 2011), which act as an antifungal agent to control pathogens (Al-Gendy et al., 2010). Membrane-bound thioglucosidase hydrolyzes glucosinolates that leads to the production of many compounds viz. epinitiles, isothiocyanates, thiocyanates, nitriles and glucose. Some of the hydrolytic breakdown products, particularly isothiocyanates, have fungicidal properties (Blazevic et al., 2010). 

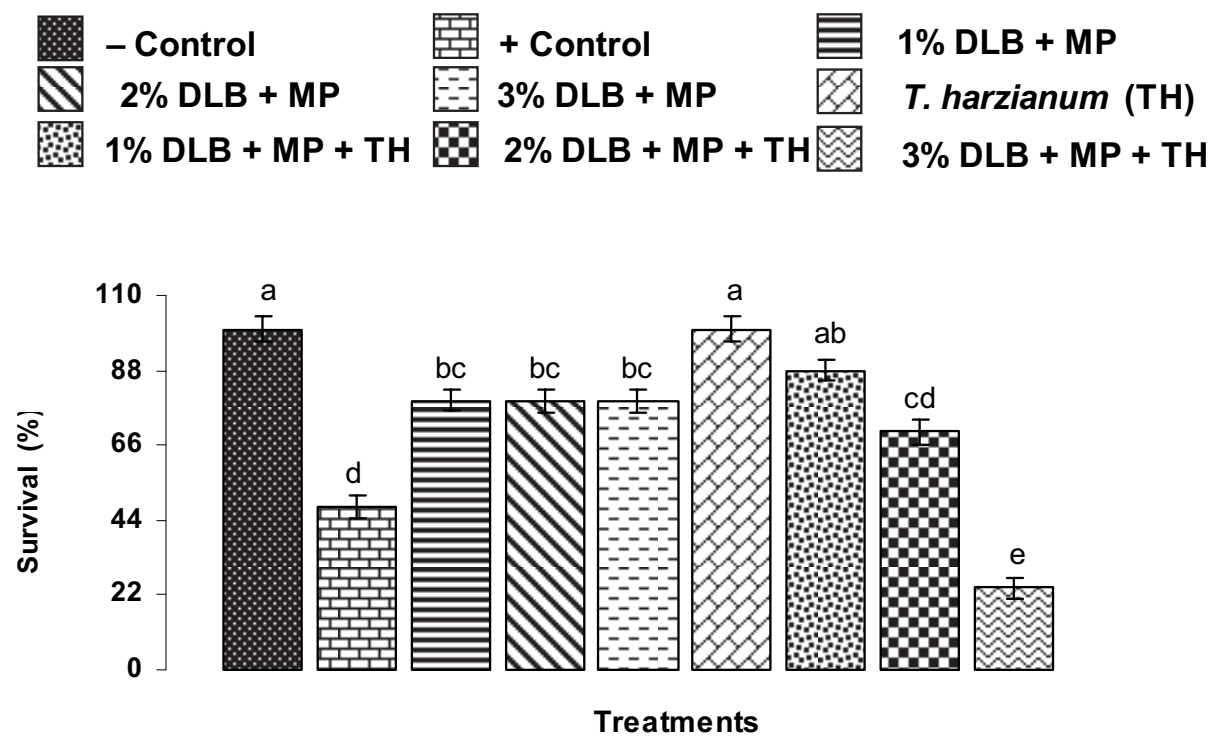

Values with different letters at their top show significant difference $(\mathrm{P} \leq 0.05)$ as determined by Tukey's HSD Test.

Vertical bars show standard errors of means of five replicates.

Figure 1 - Effect of dry leaf biomass (DLB) of Sisymbrium irio, Macrophomina phaseolina (MP) and Trichoderma harzianum on survival percentage of mungbean plants.

T. harzianum alone inoculated plants showed 100\% survival. However, in combined application treatments of $T$. harzianum and dry leaves of $S$. irio, the plant survival percentage gradually decreased, with an increase in the dose of leaf amendment. A maximum reduction of $76 \%$ in plant survival was recorded where T. harzianum was inoculated in combination with $3 \%$ dose of leaf amendment (Figure 1). Trichoderma species generally inhibit the growth of different fungi by both physical and chemical interactions, by releasing a number of compounds responsible for the induction of localized or systemic resistance responses in plants (Gary et al., 2004). Akrami et al. (2011) also studied the biocontrol effects of Trichoderma species against different fungi and obtained promising results. Key factors involved in the antagonistic relation are faster metabolic rates of Trichoderma, anti-microbial metabolites and physiological conformation. The mechanisms involved in the interaction between Trichoderma and other fungi are the competition for food and space, mycoparasitism, antibiosis by secondary metabolites and enzymes (Mausam et al., 2007).

\section{Effect of soil amendments on shoot and root growth}

In negative control treatment, the shoot length was $24 \mathrm{~cm}$. M. phaseolina inoculation in positive control treatment significantly reduced the shoot length by $26 \%$ as compared to negative control treatment. Similarly, M. phaseolina inoculation significantly reduced the number of leaflets, shoot biomass and root biomass by $51 \%, 66 \%$ and $78 \%$, respectively, in negative control treatment. Different soil amendments, except for the combined application of T. harzianum and $3 \%$ leaf biomass, alleviated biotic stress of $M$. phaseolina on different shoot and root growth parameters to variable extents. The highest increase of $153 \%, 71 \%, 181 \%$ and $300 \%$ in shoot length, number of leaflets, shoot biomass and root biomass over positive control treatment, respectively, was recorded due to $1 \%$ of leaf biomass amendment. An increase in the dose of leaf biomass amendment, either alone or in combination with $T$. harzianum gradually decreased various shoot and root growth parameters (Figure 2A and D).

\section{Effect of soil amendments on reproductive growth}

Flower initiation was started 33 days after sowing (DAS) in negative control treatment, which was significantly delayed by 10 days (43 DAS) in positive control treatment. Flower initiation in 
1-3\% of leaf amendment treatments was started from 36-38 DAS. Similarly, in the T. harzianum inoculation, either alone or in combination with $1 \%$ and $2 \%$ leaf amendment, flowering started 35-36 DAS. A maximum delay of 14 days (47 DAS) was recorded due to the combined application of T. harzianum and 3\% leaf amendment treatment (Figure 3A).

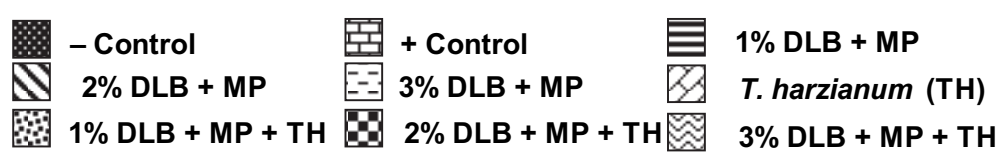

(A)

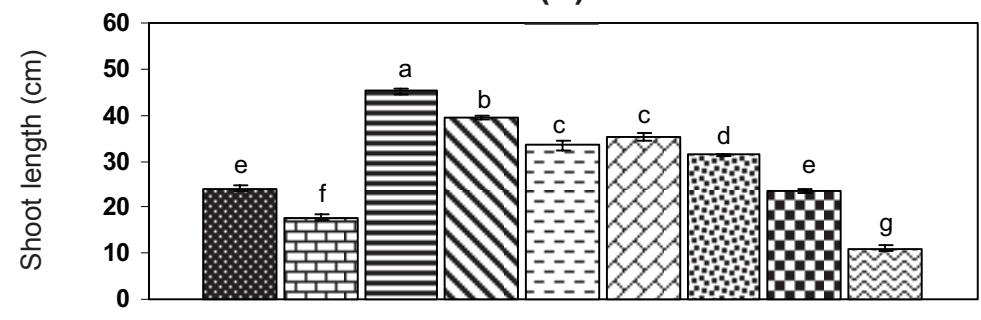

Treatments

(B)

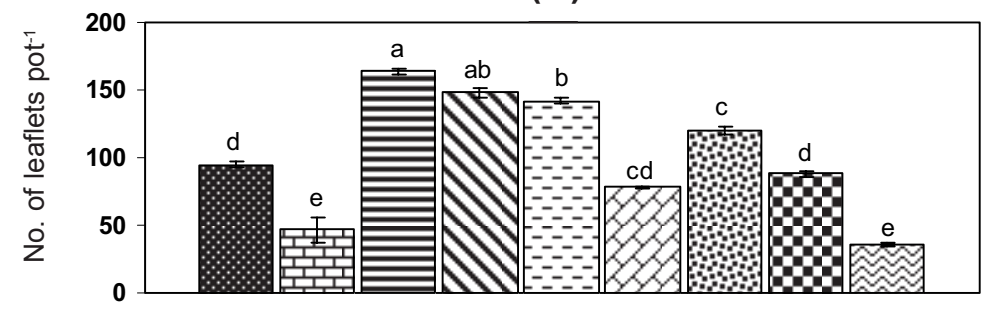

Treatments

(C)

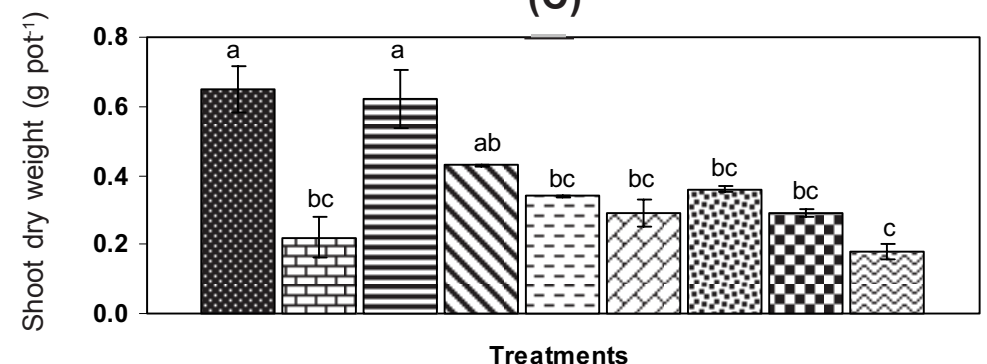

(D)

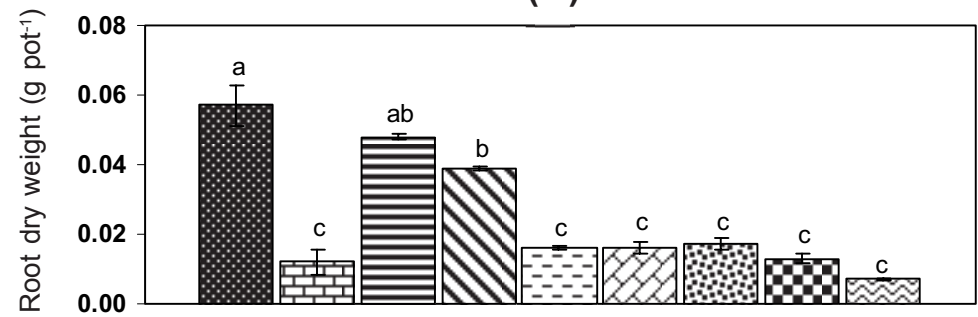

Treatments

Values with different letters at their top show significant difference $(\mathrm{P} \leq 0.05)$ as determined by Tukey's HSD Test. Vertical bars show standard errors of the mean of five replicates.

Figure 2 - Effect of dry leaf biomass (DLB) of Sisymbrium irio and Trichoderma harzianum on shoot and root growth of mung bean under biotic stress of Macrophomina phaseolina. 


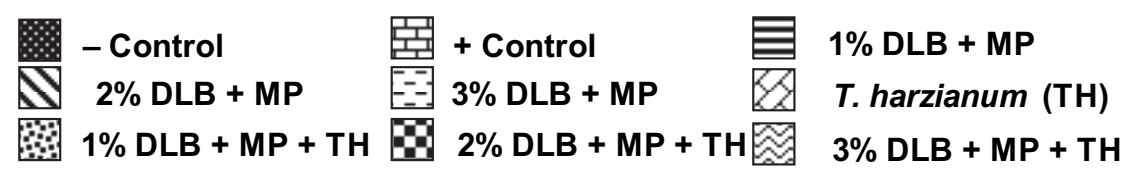

(A)

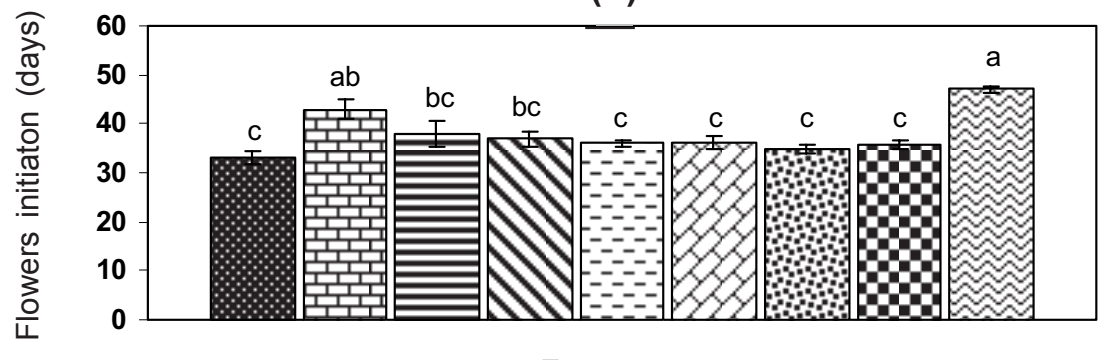

Treatments

(B)

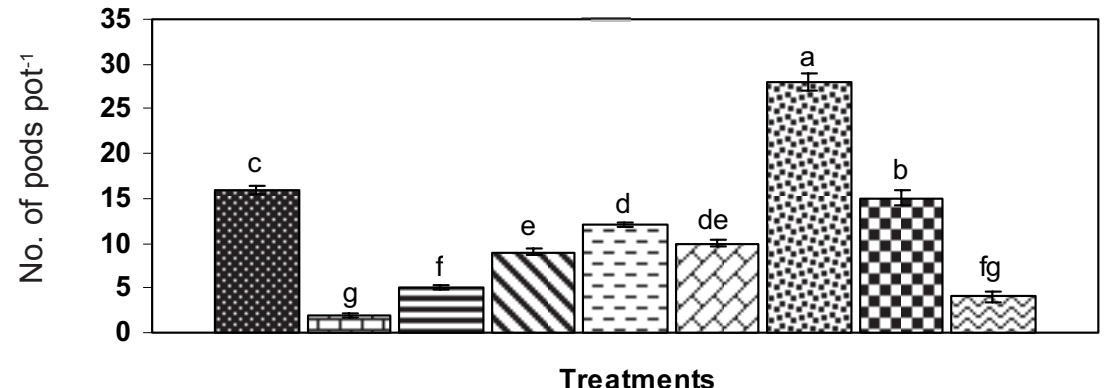

(C)

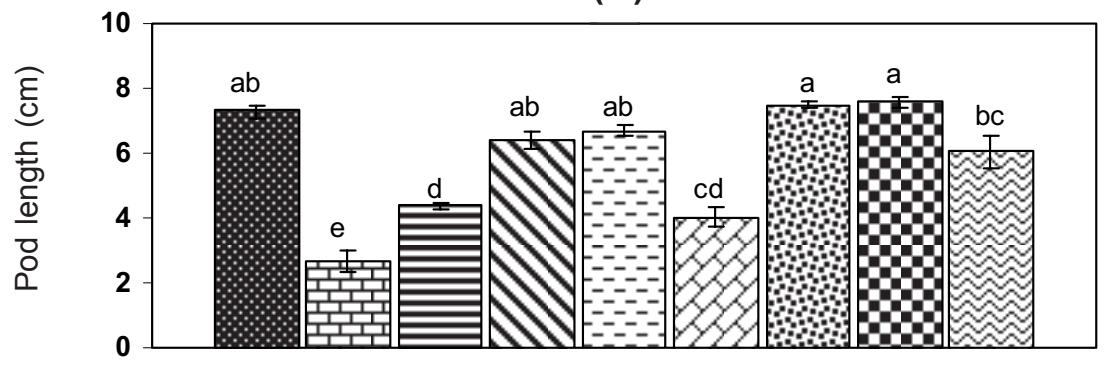

Treatments

(D)

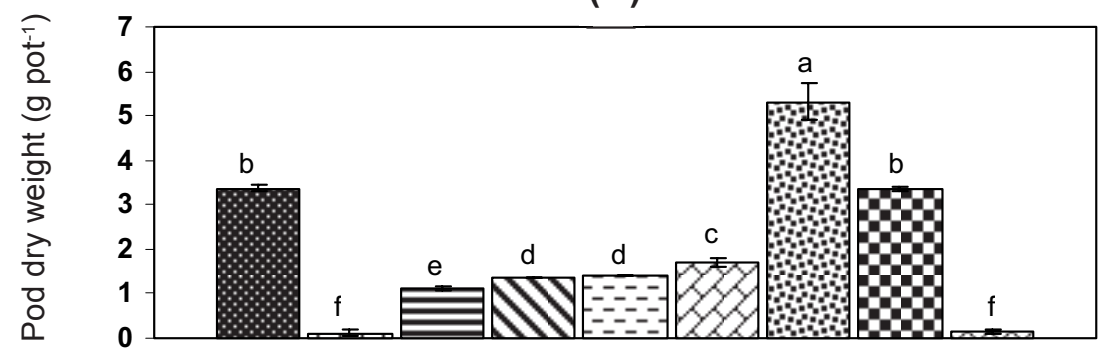

Treatments

Values with different letters at their top show significant difference $(\mathrm{P} \leq 0.05)$ as determined by Tukey's HSD Test. Vertical bars show standard errors of the mean of five replicates.

Figure 3 - Effect of dry leaf biomass (DLB) of Sisymbrium irio and Trichoderma harzianum on the reproductive growth of mung bean under biotic stress of Macrophomina phaseolina. 
Number and dry weight of pods showed similar trends in response to the application of M. phaseolina, T. harzianum and S. irio leaf biomass. There were 16 pods having $3.37 \mathrm{~g}$ dry weight per pot in negative control treatment. $M$. phaseolina inoculation significantly reduced number and dry weight of pods by $88 \%$ and $97 \%$ respectively, in negative control treatment. Soil amendment with different doses of dry leaves of $S$. irio significantly increased the number and dry weight of pods by $150-500 \%$ and $918-1172 \%$ over positive control, but these parameters still remained lower by $25-69 \%$ and $58-67 \%$ than negative control treatment, respectively. $T$. harzianum inoculation significantly enhanced the number and dry weight of pods in positive control treatment. The highest number (28) and dry weight of pods (5.32 g) were recorded in treatment where T. harzianum was inoculated in combination with $1 \%$ S. irio leaf amendment, which were $75 \%$ and $58 \%$ higher than negative control treatment, respectively. A further increase in leaf amendment resulted in a decline in these parameters. Consequently, the number and dry biomass of pods at par with negative control treatment were obtained in treatment where T. harzianum inoculation was carried out in combination with $2 \%$ S. irio leaf amendment (Figure $3 \mathrm{~B}$ and D).

The average pod length in negative control treatment was $7.36 \mathrm{~cm}$; it was reduced to $2.66 \mathrm{~cm}$ in positive control treatment due to $M$. phaseolina inoculation. Different doses of leaf amendment significantly increased pod length by $64-152 \%$ in positive control treatment. $T$. harzianum inoculation increased the pod length by $51 \%$ as compared to positive control treatment. The highest increase of $181 \%$ and $184 \%$ in pod length was recorded in treatments where T. harzianum inoculation was in combination with $1 \%$ and $2 \%$ S. irio leaf amendment, respectively (Figure 3C).

\section{Effect of soil amendments on grain yield and harvest index}

Grain yield in control treatment was $2.23 \mathrm{~g} \mathrm{pot}^{-1}$; it was significantly reduced by $82 \%$ due to M. phaseolina inoculation. Separate applications of $T$. harzianum and S. irio leaf amendment showed an insignificant effect on grain yield, compared to positive control treatment. The highest grain yield (3.62 g pot $^{-1}$ ) was recorded in a combined application of $T$. harzianum and $1 \%$ S. irio leaf amendment that was $62 \%$ and $805 \%$ higher than negative and positive control treatments, respectively. The effect of various treatments on the number of seeds per pod and harvest index was generally similar to the effect on grain yield, except for the fact that $T$. harzianum also significantly enhanced the number of seeds per pod in positive control treatment (Figure 4).

\section{Effect of soil amendments on plant physiology}

Protein content varied from $0.647-2.23 \mathrm{mg} \mathrm{g}^{-1}$ and $0.663-2.03 \mathrm{mg} \mathrm{g}^{-1}$ of plant fresh weight after 35 and 70 days of sowing, respectively. During both growth stages, the lowest protein content was recorded in positive control treatment where only $M$. phaseolina inoculum was added to the soil. During both growth stages, the difference in protein content between negative and positive control treatments was insignificant. However, all the leaf amendments and T. harzianum inoculated treatments significantly enhanced protein content over negative as well as positive control treatments. There was $39-201 \%$ and $58-243 \%$ increase after 35 days of sowing and $37-153 \%$ and $66-206 \%$ increase after 70 days of sowing in protein content due to different leaf amendment and T. harzianum treatments over the negative and positive control treatments, respectively. The highest increase in protein content over control treatments was recorded in $1 \%$ soil amendment with $S$. irio leaves followed by $T$. harzianum inoculation alone at both the growth stages (Figure 5A). The significant decrease in the protein content of leaves as a result of a pathogen infection could be related to the generation of reactive oxygen species (ROS) during the hypersensitive response (HR) (Houssien et al., 2010). The ROS production initiation is one of the first events after the recognition of a pathogen by a host plant (Baker and Orlandi, 1995). It may induce lipid peroxidation, and may modify or damage DNA and proteins (Adam et al., 1995). Besides, microbial interactions with plant roots may deeply influence the plant nutrient status through a disturbing level of soil $\mathrm{N}, \mathrm{P}, \mathrm{K}, \mathrm{Ca}, \mathrm{Zn}$ and $\mathrm{Mn}$ that may play a significant role in disease development (Ahmed and Bano, 2013). Therefore, it could be speculated that pathogens disturb the normal plant physiology by facilitating nutrients leakage from the macerated tissues (Nafie, 2003). However, all the leaf amendments and T. harzianum inoculated treatments significantly enhanced protein contents over negative as well as positive control treatments. 
The highest increase in protein contents in control treatments was recorded in $1 \%$ soil amendment with $S$. irio leaves, followed by $T$. harzianum inoculation alone at both growth stages. An increase in protein contents due to T. harzianum inoculation (Rajik et al., 2012) and plant extracts (Kamal and Bano, 2009) were also reported in many previous findings. Incorporation of soil with bioagents like $T$. harzianum or plant extracts probably act as an inducer to activate the plant's own defense mechanisms by responding with pathogensis-related (PR) proteins such as phenylalanine ammonia lyase, $\beta$-1,3-glucanase, polyphenol oxidase, phenolics and phytoalexins. These changes are possibly responsible for suppression of the pathogen activity in the host and soil (Raghavendra et al., 2013). Furthermore, soil amendment may increase soil fertility, and thereby, increase plant nutritional status, which might be responsible for enhancing the integrity of cell membranes and hence increase their permeability and decrease leakage from the macerated tissues (El Khallel, 2007).

Chlorophyll content ranged from $0.53-1.33 \mathrm{mg} \mathrm{g}^{-1}$ and $0.35-1.22 \mathrm{mg} \mathrm{g}^{-1}$ in fresh plant leaves in different treatment 35 DAS and 70 DAS, respectively. Generally speaking, all the leaf amendment and $T$. harzianum treatments showed insignificant effect on chlorophyll content 35 DAS, compared to negative control treatment, while there was a significant increase (149\%) in chlorophyll content in positive control treatment due to $3 \%$ leaf amendment treatment. On day 70 of the growth stage, all treatments showed significantly lower chlorophyll contents (32-71\%) than the negative control treatment. The highest reduction was recorded in positive control treatment. Chlorophyll contents were gradually increased by increasing the amount of dry leaf amendment, either alone or in combination with T. harzianum. An increase in chlorophyll content due to $3 \%$ leaf amendment either alone (144\%) or in combination with $T$. harzianum (100\%) was found significant in positive control treatment. The effect of $T$. harzianum alone was insignificant in positive control treatment (Figure 5B). A reduction in chlorophyll contents of infected plants could be due to the increasing amount of destructive enzymes called chlorophyllase. On the other hand, the incorporation of soil amendments increased chlorophyll contents in positive control treatment, possibly due to the increase in chloroplast for maintaining plant photosynthesis (Rahdari et al., 2012).

Minimum sugar contents of $0.17 \mathrm{mg} \mathrm{g}^{-1}$ and $0.25 \mathrm{mg} \mathrm{g}^{-1}$ of fresh leaf biomass were recorded in positive control treatment, which were significantly lower by $54 \%$ and $49 \%$ than negative control tratment 35 DAS and 70 DAS, respectively. All the leaf amendment and T. harzianum treatments significantly enhanced the sugar content by $117-184 \%$ and $62-124 \%$ in positive control treatment 35 DAS and 70 DAS, respectively. Generally speaking, the sugar content was increased by increasing the dose of leaf amendment, either with or without $T$. harzianum (Figure $5 \mathrm{C}$ ). Soluble sugars are involved in the responses to a variety of stresses, and act as metabolites and nutrients signaling molecules that activate specific or hormonal-crosstalk transduction pathways, leading to a significant gene expression alteration (Couée et al., 2006). It seems that the total sugar variation during infection is due to its utilization by fungi for their own growth (Misra et al., 2008). On the other hand, increased sugar contents after the incorporation of soil amendments or $T$. harzianum might be related to enhancing the sink-strength of roots and thereby stimulating carbohydrate biosynthesis in the shoots and their transport into the roots (Hause and Fester, 2002). Previously increases in soluble sugar contents in maize, radish and soybean by the application of heliotrope leaf extracts, maize and leaf extracts of Acacia and Eucalyptus have been documented (Abdulghader and Nabat, 2008; Ahmed and Bano, 2013).

Catalase activity in negative control treatment was 3.03 and 2.15 units $\mathrm{min}^{-1} \mathrm{mg}^{-1}$ protein 35 DAS and 70 DAS, respectively. M. phaseolina inoculation significantly reduced catalase activity by $66 \%$ in positive control treatment on day 35 of the growth stage while at later growth stage, the effect was insignificant. Different doses of leaf amendment significantly enhanced catalase activity by $176-294 \%$ in positive control treatment, on day 35 DAS. T. harzianum inoculation showed much more stimulatory effect on catalase activity than leaf amendment, resulting in a $442 \%$ and $179 \%$ increase in positive control treatments 35 DAS and 70 DAS, respectively. The highest catalse activity was recorded in treatments where $T$. harzianum was inoculated in combination with 3\% dose of leaf amendment. In this treatment, catalase activity was 6.07 and 8.80 units min $^{-1} \mathrm{mg}^{-1}$ protein 35 DAS and 70 DAS, which was 498\% and 259\% higher than catalase activity in positive control treatment, respectively (Figure 5D). 


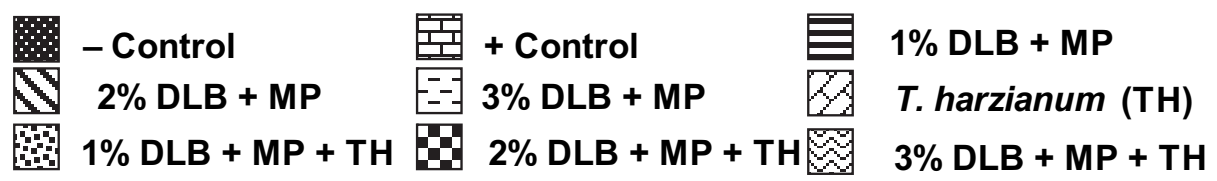

(A)

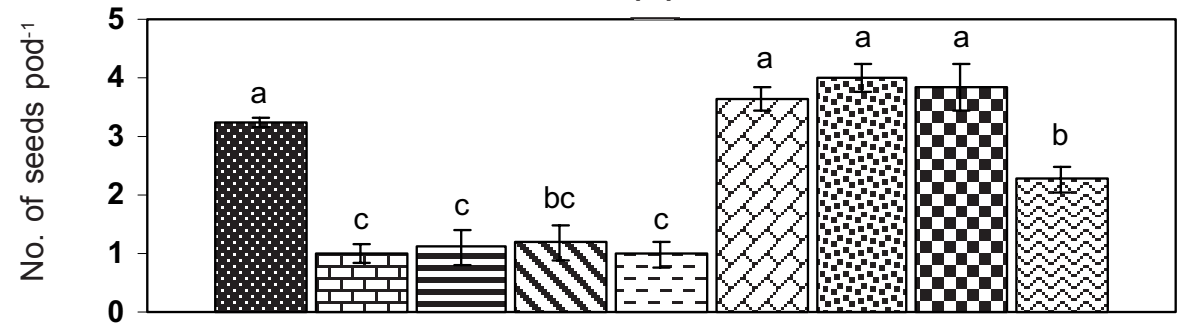

Treatments

(B)

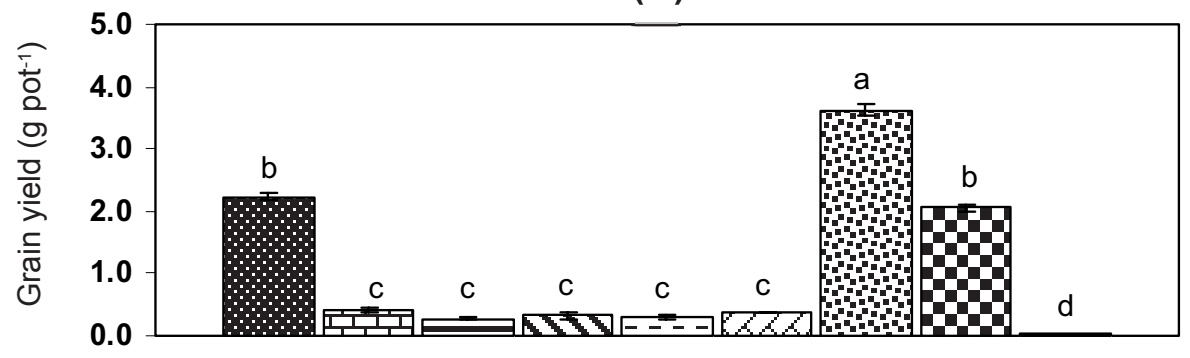

Treatments

(C)

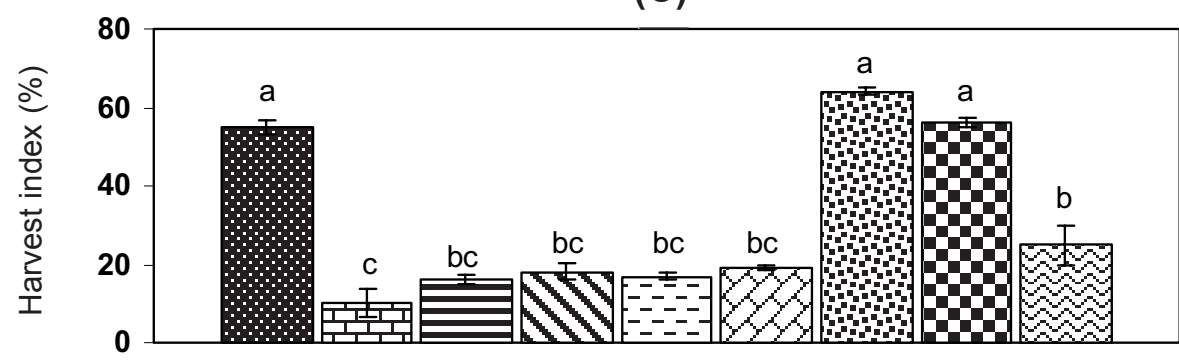

Treatments

Values with different letters at their top show significant difference $(\mathrm{P} \leq 0.05)$ as determined by Tukey's HSD Test. Vertical bars show standard errors of the mean of five replicates.

Figure 4 - Effect of dry leaf biomass (DLB) of Sisymbrium irio and Trichoderma harzianum on grain yield, and harvest index of mung bean under biotic stress of Sclerotium rolfsii.

The highest water content of $65 \%$ and $70 \%$ were recorded in negative control treatment on day 35 DAS and 70 DAS, respectively. Inoculations of M. phaseolina, either alone or in combination with different soil amendments, reduced relative water contents by $14-49 \%$ and $34-55 \%$ after 35 and 70 days of growth, respectively (Figure $5 \mathrm{E}$ ). A decrease in the water potential is a primary response in stressed plants, leading to decreased water use efficiency and resulting in overall toxic damages and yield decline (Chaum and Kirdmanee, 2009). Reductions in leaf water contents possibly cause turgor loss, which in turn results in stomatal closure and limits dioxide carbon assimilation and lowers photosynthetic rate (Rahdari et al., 2012). 


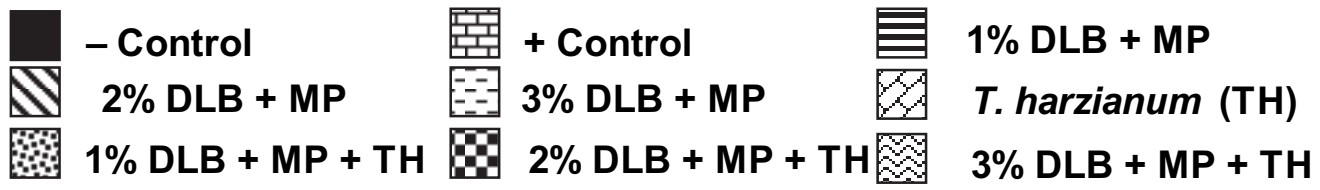

(A)

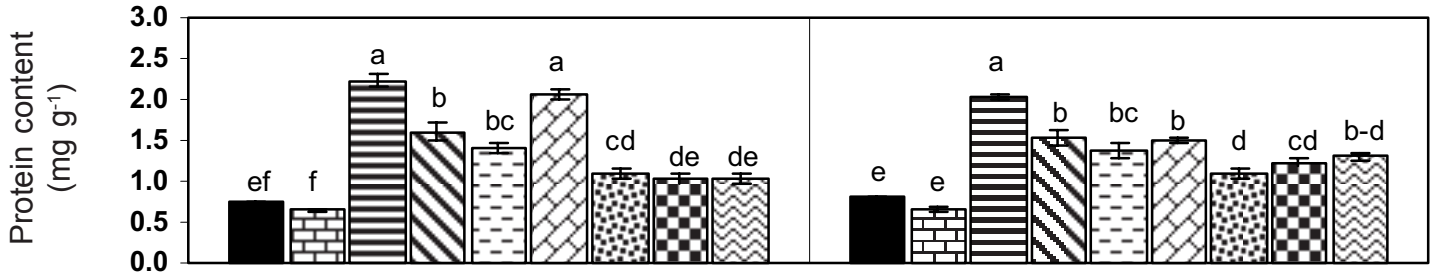

(B)

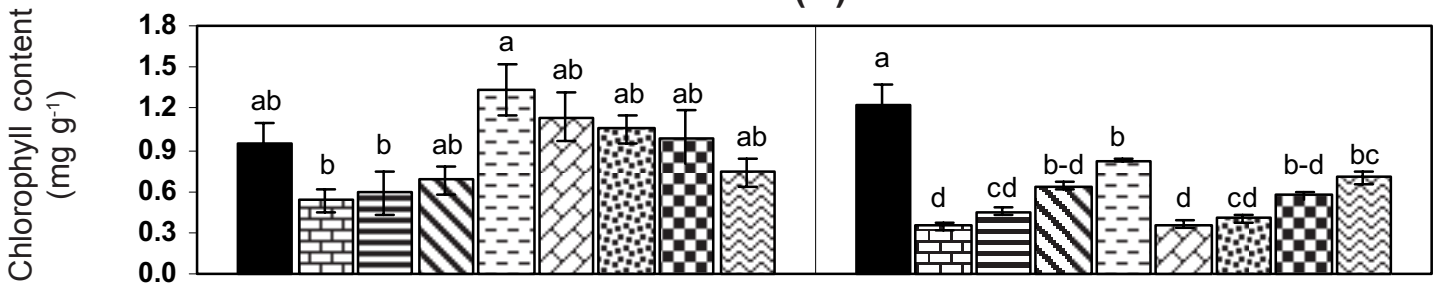

(C)
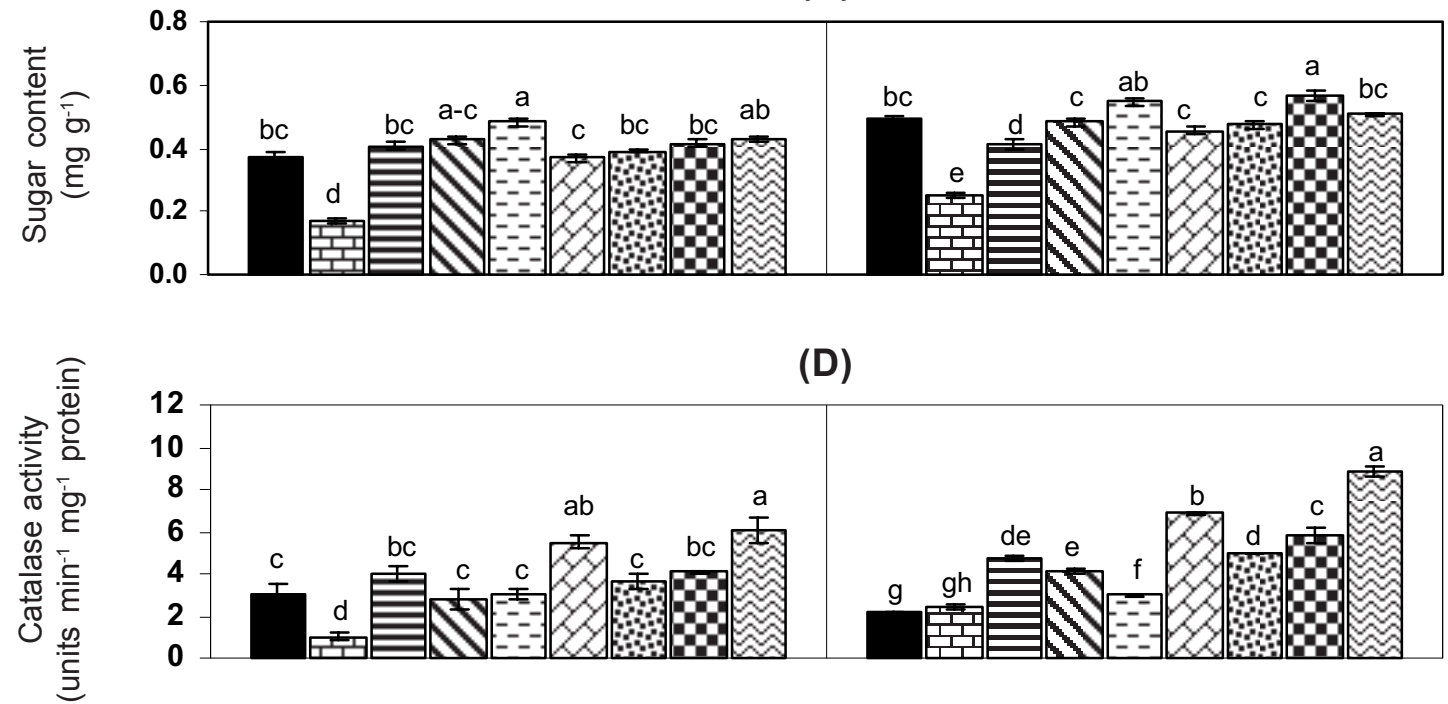

(E)

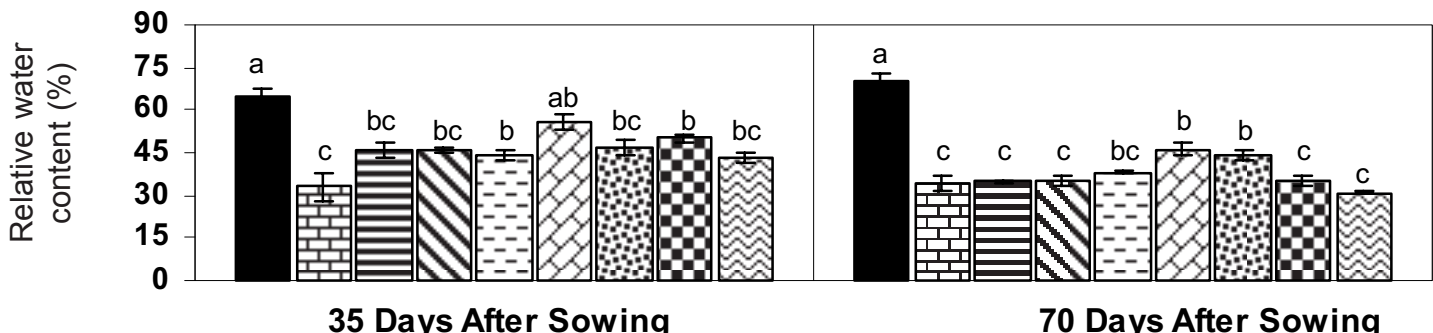

Values with different letters at their top show significant difference $(\mathrm{P} \leq 0.05)$ as determined by Tukey's HSD Test. Vertical bars show standard errors of the mean of three replicates.

Figure 5 - Effect of dry leaf biomass (DLB) of Sisymbrium irio, Macrophomina phaseolina (MP) and Trichoderma harzianum on protein, chlorophyll, sugar and relative water content, and catalase activity of mung bean leaves after 35 and 70 days of growth. 
This study concludes that an effective management of charcoal rot in mung bean can be achieved by applying $T$. harzianum in combination with $1 \%$ leaf dry biomass of $S$. irio.

\section{REFERENCES}

Abdulghader K., Nabat M.N. Chemical stress induced by heliotrope (Heliotropium europaeum L.) allelochemicals and increased activity of antioxidant enzymes. Pak J Biol Sci. 2008;11:915-9.

Adam A.L.et al. Enzymes regulating the accumulation of active oxygen species during the hypersensitive reaction of bean to Pseudomonas syringae pv. phaseolicola. Planta. 1995; 197: 240-9.

Agricultural Statistics of Pakistan 2010-11. Statistics Division, Pakistan Bureau of Statistics, 2011.

Ahmed N., Bano A. Impact of allelopathic potential of maize (Zea mays L.) on physiology and growth of soybean [Glycine max (L.) Merr.]. Pak J Bot. 2013;45:1187-92.

Akrami H., Golzary M.H., Ahmadzadeh M. Evaluation of different combinations of Trichoderma species for controlling Fusarium rot of lentil. Afr J Biotechnol. 2011;10:2653-8.

Al-Gendy A.A., El-Gindi A.S., Ateya A.M. Glucosinolates, volatile constituents and biological activities of Erysimum corinthium Boiss. (Brassicaceae). Food Chem. 2010;118:519-24.

Arnon D.I. Copper enzymes in isolated chloroplasts. Polyphenol oxidase in Beta vulgaris. Plant Physiol. 1949;25:1-15.

Baker C.J., Orlandi E.W. Reactive oxygen in plant pathogenesis. Ann Rev Phytopathol. 1995;33:299-321.

Bla•eviæ I. et al. Glucosinolates, glycosidically bound volatiles and antimicrobial activity of Aurinia sinuata (Brassicaceae). Food Chem. 2010;121:1020-8.

Chaum S., Kirdmanee C. Effect of salt stress on proline accumulation, photosynthetic ability and growth characters in two Maize cultivars. Pak J Bot. 2009;41:87-98.

Couée I. et al. Involvement of soluble sugars in reactive oxygen species balance and responses to oxidative stress in plants. $\mathbf{J}$ Exp Bot. 2006;57:449-59.

Dhingra O.D., Sinclair J.B. Biology and Pathology of Macrophomina phaseolina. Viçosa, MG: Universidade Federal de Viçosa, 1978.

El-Khallel S.M. Induction and modulation of resistance in tomato plants against Fusarium wilt disease by bioagent fungi (arbuscular mycorrhiza) and/or hormonal elicitors (jasmonic acid \& salicylic acid): 1-changes in growth, some metabolic activities and endogenous hormones related to defense mechanism. Aust J Basic Appl Sci. 2007;1:691-705.

Fuhlbohm M.J., Ryley M.J., Aitken E.A.B. Infection of mungbean seed by Macrophomina phaseolina is likely to result from localized pod infection than from systemic plant infection. Plant Pathol. 2013;62:1271-84.

Gary F. et al. Trichoderma species opportunistic avirulent plant symbionts. Nat Rev Microbiol. 2004;2:40-3.

Hause B., Fester T. Molecular and cell biology of arbuscular mycorrhiza symbiosis. Planta. 2005;221:184-96.

Houssien A.A., Ahmed S.A., Ismail A. Activation of tomato plant defense response against Fusarium wilt disease using Trichoderma harzianum and salicylic acid under greenhouse conditions. Res J Agric Biol Sci. 2010;6:328-38.

Ilyas M.B. et al. Effect of soil fungicides on Macrophomina phaseolina sclerotium viability in soil and in soybean stem pieces. Phytopathology. 1975;66:355-9.

Javaid A., Saddique A. Management of Macrophomina root rot of mungbean using dry leaves manure of Datura metel as soil amendment. Span J Agric Res. 2011;9:901-5.

Javaid A.; Iqbal D. Management of collar rot of bell pepper (Capsicum annuum L.) by extracts and dry biomass of Coronopus didymus shoot. Biol Agric Hort. 2014;30:164-72.

Javaid A., Rauf S. Management of basal rot disease of onion with dry leaf biomass of Chenopodium album as soil amendment. Inter J Agric Biol. 2015;17:142-8.

Javaid A. et al. Management of Macrophomina phaseolina by extracts of an allelopathic grass Imperata cylindrica. Pak J Agric Sci. $2015 ; 15: 37-41$. 
Kamal J., Bano A. Efficiency of allelopathy of sunflower (Helianthus annuus L.) on physiology of wheat (Triticum aestivum L.). Afr J Biotechnol. 2009;8:3555-9.

Khurshid S.; Shoaib A.; Javaid A. Fungicidal potential of allelopathic weed Cenchrus pennisetiformis on growth of Fusarium oxysporum f. sp. lycopersici under chromium stress. Planta Daninha. 2016;34:453-63.

Lowry O.H. et al. Protein measurement with the folin phenol reagent. J Biol Chem. 1951;193:265-75.

Lewis J.A., Papavizas G.C. Damping-off of sugarbeets caused by Aphanomyces cochlioides as affected by soil amendments and chemicals in green house. Plant Dis Rep. 1971;55:440-4.

Maehly A.C., Chance, B. The assay of catalases and peroxidases. In: Methods of Biochemical Analysis. Glick D. (Ed.), Inter Science Publications, Inc., New York, 1967. v.1.

Manning W.J., Crossan D.F. Field and greenhouse studies on the effect of plant amendments on Rhizoctonia hypocotyle rot of snapbean. Plant Dis Rep. 1969;53:227-31.

Mausam R. et al. Antagonistic fungi Trichoderma spp.: Panoply of biological control. Biochem Eng J. 2007;37:1-20.

Misra R.S. et al. Biochemical alterations induced in taro in response to Phytophthora colocasiae infection. Adv Nat Appl Sci. 2008;2:112-21.

Muehlchen A.M., Rand R.E., Parke J.L. Evaluation of crucifer green manure for controlling Aphanomyces root rot in pea. Plant Dis. 1990;74:651-4.

Nafie E.M. The possible induction of resistance in Lupinus termis L. against Fusarium oxysporum by Streptomyces chibaensis and its mode of action: 1. Changes in certain morphological criteria and biochemical composition related to induced resistance. Int $\mathbf{J}$ Agric Biol. 2003;5:463-72.

Nair R.M. et al. Biofortification of mungbean (Vigna radiata) as a whole food to enhance human health. J Sci Food Agric. 2013;93:1805-13.

Nair R.M. et al. Mineral and phenolic concentrations of mungbean [Vigna radiata (L.) R. Wilczek var. radiata] grown in semi-arid tropical India. J Food Compos Anal. 2015;39:23-32.

Nelson N. A photometric adaptation of the Somogyi method for determination of glucose. J Biol Chem. 1944;153:375-80.

Raghavendra V.B. et al. Induction of systemic resistance by biocontrol agents against bacterial blight of cotton caused by xanthomonas campestris pv. malvacearum. Sci J Plant Pathol. 2013;2:59-69.

Rahdari P., Tavakoli S., Hosseini S.M. Studying of salinity stress effect on germination, proline, sugar, protein, lipid and chlorophyll content in purslane (Portulaca oleracea L.) leaves. J Stress Physiol Biochem. 2012;8:182-93.

Rajik M., Biswas S.K., Shakti S. Biochemical basis of defense response in plant against Fusarium wilt through bio-agents as an inducers. Afr J Agric Res. 2012;7:5849-57.

Riaz T., Khan S.N., Javaid A. Management of Fusarium corm rot of gladiolus (Gladiolus grandiflorus sect. Blandus cv. Aarti) by using leaves of allelopathic plants. Afr J Biotechnol. 2010;9:4681-6.

Ramirez-Villapudua J., Munnecke D.E. Effect of solar heating and soil amendment of cruciferous residues on Fusarium oxysporum f. sp. conglutinans and other organisms. Phytopathology. 1988;78:289-95.

Subbarao K.V., Hubbard J.C., Koike S.T. Effect of broccoli residue on Verticillium dahliae and microsclerotia and wilt incidence in cauliflower. Phytopathology. 1994;84:1092.

Sun B. et al. Variation of glucosinolates in three edible parts of Chinese kale (Brassica alboglabra Bailey) varieties. Food Chem. 2011;124:941-7.

Troncoso R. et al. Analysis of the isothiocyanates present in cabbage leaves extract and their potential application to control Alternaria rot in bell peppers. Food Res Int. 2005;38:701-8.

United States Department of Agriculture - USDA. National Nutrient Database. 2010 (accessed on: 15 march 2012] Available at: http://www.nal.usda.gov/fnic/foodcomp/search/

Wheatherley P.E. Studies in the water relations of cotton plants. The field measurement of water deficit in leaves. New Phytol. 1950;49:81-7. 